\title{
EVALUASI PENGGUNAAN ANTIBIOTIK PROFILAKSIS PADA PASIEN BEDAH KATEGORI HIGHLY RECOMMENDED DI RUMAH SAKIT “X” KOTA PRABUMULIH
}

\author{
Rangti Annisa Harartasyahrani ${ }^{1}$, Sarmalina Simamora ${ }^{2 *}$ \\ ${ }^{1}$ Jurusan Farmasi Poltekkes Kemenkes Palembang \\ Email: rangtiannisahs@gmail.com \\ 2*Jurusan Farmasi Poltekkes Kemenkes Palembang \\ Email: sarmalina@poltekkespalembang.ac.id
}

Masuk: 25-08-2020, revisi: 29-03-2021, diterima untuk diterbitkan: 31-03-2021

\begin{abstract}
ABSTRAK
Berdasarkan Permenkes RI No.2406/Menkes/per/XII/2011 tentang Pedoman Umum Penggunaan Antibiotik bahwa pemberian antibiotik profilaksis ditujukan untuk menurunkan dan mencegah terjadinya Infeksi Luka Operasi (ILO), menghambat munculnya resistensi, menurunkan morbiditas dan mortalitas pasien, serta untuk meminimalkan biaya pelayanan kesehatan dan pemberian antibiotik profilaksis pada prosedur bedah kategori highly recommended telah terbukti tegas dan efektif. Namun, dari beberapa penelitian masih banyak dijumpai ketidaksesuaian dalam penggunaan antibiotik profilaksis serta terdapat beberapa kasus pada pasien prosedur bedah kategori highly recommended yang tidak diberikan antibiotik profilaksis maka penelitian ini bertujuan untuk mengevaluasi penggunaan antibiotik profilaksis pada pasien bedah kategori highly recommended. Penelitian ini merupakan penelitian observasional. Data diperoleh secara retrospektif melalui penelusuran data rekam medik pasien bedah kategori highy recommended di Rumah Sakit "X" Kota Prabumulih periode Januari-Desember 2019 dengan menggunakan metode purposive sampling yang selanjutnya dianalisis secara deskriptif menggunakan pedoman yang berlaku. Dari 77 rekam medik pasien yang terkumpul ditemukan 1 pasien $(1,30 \%)$ yang tidak mendapat antibiotik profilaksis dan dari 76 data rekam medik yang memenuhi kriteria inklusi terdapat 119 penggunaan antibiotik profilaksis dan secara keseluruhan didapat kesesuaian sebanyak 8 penggunaan (6,72\%). Kesesuaian berdasarkan jenis antibiotik sebanyak $110(92,44 \%)$, dosis antibiotik sebanyak $95(86,36 \%)$, rute pemberian sebanyak $110(100 \%)$, waktu pemberian sebanyak $103(93,64 \%)$, interval pemberian sebanyak $8(7,27 \%)$, dan lama pemberian sebanyak $44(40 \%)$. Secara keseluruhan, penggunaan antibiotik profilaksis belum sepenuhnya sesuai dan ketidaksesuaian yang paling banyak ditemukan yaitu pada interval pemberian.
\end{abstract}

Kata Kunci : Antibiotik profilaksis; Bedah; Evaluasi;Highly Recommended

\begin{abstract}
Based on Permenkes RI No.2406 / Menkes / per / XII / 2011 on General Guidelines for the Use of Antibiotics that prophylaxis antibiotics intended to reduce and prevent to occurrence of Surgical Site Infection (SSI), inhibiting the emergence of resistance, reduce the morbidity and mortality of patients, as well as to minimize the value of health care and prophylaxis antibiotics in highly recommended surgical procedures has been proven to be firm and effective. However, from several studies there are still many discrepancies in the use of prophylaxis antibiotics and there are several cases in patients with highly recommended surgical procedures that are not given prophylaxis antibiotics, so this research aims to evaluate the use of prophylaxis antibiotics in highly recommended surgical patients. This research was observational research. The data was obtained retrospectively by searching the medical record data of highly recommended surgical patient in Hospital "X” Prabumulih period of January-December 2019 using the Purposive sampling method which is further analyzed descriptively using the applicable guidelines. From 77 medical records of patients collected found 1 patient (1.30\%) who did not get antibiotics and from 76 medical record data that met the inclusion criteria there were 119 prophylaxis antibiotic use and overall there were 8 uses (6.72\%). Suitability based on antibiotic type as much as 110 (92.44\%), antibiotic doses as many as 95 (86.36\%), delivery route as much as 110 (100\%), delivery time as much as 103 (93.64\%), delivery interval of 8 (7.27\%), and length of delivery as much as 44 (40\%). Overall, the using of prophylaxis antibiotics is not fully appropriate and the most common discrepancies are found at the interval of administration.
\end{abstract}

Keywords: Prophylaxis antibiotics; Surgery; Evaluation; Highly Recommended 


\section{PENDAHULUAN}

Surgical Site Infection (SSI) merupakan salah satu faktor risiko yang paling sering menyebabkan Health Care Assosiated Infections (HAIs) atau infeksi nosokomial (Kemenkes, 2017). Menurut survei WHO terdapat sekitar 5\%-34\% kejadian Surgical Site Infection (SSI) di dunia. Hasil penelitian menunjukkan bahwa sebesar 56,67\% angka kejadian Surgical Site Infection (SSI) di RSUP Dr. Moehammad Hoesin Palembang (Yuwono, 2013, p.23). Tingginya angka kejadian Surgical Site Infection (SSI) memungkinkan dapat meningkatkan biaya perawatan dan pelayanan kesehatan. Pemberian antibiotik profilaksis ditujukan untuk menurunkan dan mencegah terjadinya infeksi luka operasi, menghambat munculnya resistensi, menurunkan morbiditas dan mortalitas pasien pasca operasi, serta untuk meminimalkan biaya pelayanan kesehatan (Kemenkes, 2011).

Antibiotik profilaksis merupakan antibiotik yang diberikan sebelum terjadinya infeksi yaitu diberikan sebelum, saat akan dilakukan pembedahan, hingga 24 jam pasca pembedahan. Terdapat bebebapa kategori rekomendasi dalam pemberian antibiotik profilaksis pada prosedur bedah, salah satu diantaranya adalah highly recommended. Dalam kategori ini diartikan bahwa antibiotik yang diberikan terbukti tegas menurunkan biaya perawatan, menurunkan morbiditas dan secara keseluruhan menurunkan konsumsi antibiotik pasien (Sumanti, et al., 2016, p.27). Pada penelitian tahun 2016 di Rumah Sakit Islam Sultan Agung Semarang tentang efektivitas penggunaan antibiotik profilaksis pada bedah sesar yang termasuk kategori highly recommended yaitu $100 \%$ efektif mencegah infeksi (Karminingtyas et al., 2018, p.22). Pada penelitian di negara-negara berpenghasilan rendah, menunjukkan bahwa pemberian antibiotik profilaksis lebih efektif dan lebih hemat (Goranitis et al., 2019, p.1280).

Namun, pada beberapa penelitian sebelumnya dijumpai ketidakrasionalan penggunaan antibiotik profilaksis, seperti pada penelitian yang dilakukan Megawati et al (2015) di RSI Sultan Agung Semarang bahwa penggunaan antibiotik profilaksis yang rasional sebesar 0\% (Megawati et al., 2015, p.127). Hasil penelitian mengenai evaluasi kualitatif penggunaan antibiotik profilaksis di instalasi bedah sentral RSUD Kraton menunjukkan bahwa penggunaan antibiotik yang rasional sebesar 10\% sedangkan 90\% tidak rasional (Muthoharoh et al., 2019, p.493). Pada penelitian di RSUD Tugurejo tahun 2014, penggunaan antibiotik profilaksis yang rasional hanya sebesar 44\%, sisanya penggunaan antibiotik tidak rasional (Antoni dan Supadmi, 2016, p.1). Selain itu, masih dijumpai pasien bedah yang tidak mendapatkan antibiotik profilaksis, seperti pada penelitian yang dilakukan Hamidy et al (2016) di RSUD Arifin Achmad Provinsi Riau bahwa sebanyak 273 pasien bedah sesar 56,3\% tidak mendapat antibiotik profilaksis (Hamidy et al., 2016, p.35), hal yang sama juga terjadi di Rumah Sakit Islam Samarinda bahwa sebanyak 9,93\% (15 pasien) tidak mendapatkan antibiotik profilaksis (Sumanti, et al., 2016, p.22), sedangkan bedah sesar merupakan prosedur bedah yang termasuk kategori highly recommended untuk diberikan antibiotik profilaksis (Kemenkes, 2011). Ketidaksesuaian pemberian antibiotik profilaksis di beberapa rumah sakit dapat memungkinkan terjadinya Infeksi Luka Operasi (ILO). Hasil penelitian juga menunjukkan bahwa adanya pengaruh waktu pemberian antibiotik profilaksis terhadap kejadian Surgical Site Infection (SSI) yang signifikan (Amelia et al., 2019, p.109). 
Oleh karena pentingnya penggunaan antibiotik profilaksis pada tindakan pembedahan, namun masih banyak dijumpai ketidaksesuaian dalam penggunaan antibiotik profilaksis pada beberapa penelitian sebelumnya serta terdapat beberapa kasus pada pasien prosedur bedah kategori highly recommended yang tidak diberikan antibiotik profilaksis maka penelitian ini bertujuan untuk mengevaluasi penggunaan antibiotik profilaksis pada pasien bedah kategori highly recommended yang dilakukan di salah satu rumah sakit swasta yang sudah terakreditasi di Kota Prabumulih.

\section{METODE PENELITIAN}

Penelitian ini merupakan penelitian observasional. Penelitian dilakukan pada bulan FebruariApril 2020 dimana data diperoleh secara retrospektif melalui penelusuran data rekam medik pasien bedah kategori highy recommended di Rumah " $\mathrm{X}$ " Kota Prabumulih periode JanuariDesember 2019 dengan menggunakan metode purposive sampling. Dari 247 pasien yang menjalani tindakan bedah di Rumah Sakit "X" Kota Prabumulih pada bulan Januari- Desember 2019, terdapat 131 pasien yang termasuk prosedur bedah dengan kategori highly recommended, dan dari 77 data rekam medik yang terkumpul, sebanyak 76 rekam medik yang memenuhi kriteria inklusi terdapat 119 penggunaan antibiotik profilaksis yang selanjutnya digunakan dalam pengolahan dan analisis data.

Analisis data dilakukan secara deskriptif berdasarkan variabel jenis antibiotik, dosis antibiotik, rute pemberian, waktu pemberian, interval pemberian, dan lama pemberian dengan membandingkan data yang diperoleh dengan ketentuan beberapa pedoman dan literatur yaitu Pedoman Umum Penggunaan Antibiotik Kemenkes (Kemenkes, 2011), SIGN 104 Antibiotic prophylaxis in surgery : A national clinical guideline (Scottish Intercollegiate Guidelines Network, 2008), Clinical Practice Guidelines for Antimicrobial Prophylaxis in Surgery (ASHP, 2013), Global Guidelines for the Prevention of Surgical Site Infection (WHO, 2016), Surgical Antibiotic Phrophylaxis Guidelines (NHS Grampian, 2014), dan Antibiotic Prophylaxis in General Surgery (NHS Tayside, 2019). Jika variabel penelitian menggunakan lebih dari satu pedoman maka bila data yang tercatat sesuai dengan ketentuan pada salah satu pedoman atau literatur saja berarti dapat dikategorikan sesuai.

\section{HASIL DAN PEMBAHASAN}

\section{Jenis Prosedur Bedah dan Perlakuan Pemberian}

Hasil penelitian menunjukkan bahwa dari ketiga jenis prosedur bedah didominasi oleh pasien dengan prosedur bedah casarean section yaitu sebanyak 62 pasien $(80,52 \%)$. Hal yang sama juga terjadi pada penelitian terkait yaitu hasil penelitian yang dilakukan Antoni \& Supadmi (2016), p.3 bahwa dari 15 jenis prosedur bedah, Casarean section merupakan jenis prosedur bedah terbanyak yaitu sebanyak 30 pasien (30\%) dari 100 pasien. Menurut World Health Organization (2015), terdapat sebesar 10-15\% proses persalinan dengan tindakan casarean section (WHO, 2015). Berdasarkan data Riset Kesehatan Dasar, angka persalinan dengan bedah sesar di Indonesia pada tahun 2013 mencapai 9,8\% dari 49.603 kelahiran (Badan Penelitian dan Pengembangan Kesehatan, 2013, p.174), sedangkan pada tahun 2018 dari 78.736 kelahiran terdapat $17,6 \%$ kelahiran yang dilakukan dengan tindakan bedah sesar (Badan Penelitian dan Pengembangan Kesehatan, 2019, p.398). Hal ini menunjukkan bahwa angka persalinan dengan 
bedah sesar di Indonesia semakin tahun semakin meningkat, dan dapat memungkinkan risiko terjadinya Surgical Site Infection (SSI) (Antoni \& Supadmi, 2016; WHO, 2015; Badan Penelitian dan Pengembangan Kesehatan, 2013, 2019).

Tabel.1 Karakteristik Jenis Prosedur Bedah Kategori Highly Recommended dan Distribusi Frekuensi Perlakuan Pemberian Antibiotik Profilaksis di Rumah Sakit "X" Kota Prabumulih Periode Januari-Desember 2019

\begin{tabular}{|c|c|c|c|c|}
\hline \multirow{2}{*}{ No. } & \multirow{2}{*}{ Jenis Prosedur Bedah } & \multirow{2}{*}{ Jumlah } & \multicolumn{2}{|c|}{ Perlakuan Pemberian } \\
\hline & & & Ya & Tidak \\
\hline 1. & Casarean section & $\begin{array}{c}62 \\
(80,52 \%)\end{array}$ & 61 & 1 \\
\hline 2. & $\begin{array}{l}\text { Transurethal resection of the } \\
\text { prostate }\end{array}$ & $\begin{array}{c}9 \\
(11,69 \%)\end{array}$ & 9 & 0 \\
\hline \multirow[t]{3}{*}{3.} & Appendictomy & $\begin{array}{c}6 \\
(7,79 \%)\end{array}$ & 6 & 0 \\
\hline & Total & 77 & 76 & 1 \\
\hline & \% Perlakuan Pemberian & & $98,70 \%$ & $1,30 \%$ \\
\hline
\end{tabular}

Secara umum, pasien sudah diberikan antibiotik profilaksis yaitu mencapai 98,70\% (76 penggunaan), namun ditemukan 1 pasien $(1,30 \%)$ yang tidak diberikan antibiotik profilaksis. Jika dibandingkan dengan penelitian sebelumnya, angka kejadian pada penelitian ini jauh lebih rendah yaitu pada penelitian yang dilakukan Hamidy et al (2016) di RSUD Arifin Achmad Provinsi Riau ditemukan sebanyak 273 pasien $(56,3 \%)$ yang tidak mendapatkan antibiotik profilaksis (Hamidy et al., 2016, p.35). Jumlah pasien di RS ini tentu lebih banyak karena kelasnya B non-pendidikan sedangkan penelitian ini dilakukan di RS kelas D, disamping itu RS UD Arifin Achmad sudah terakreditasi di dua belas layanan. Hasil penelitian Sumanti, et al (2016), p.22 di Rumah Sakit Islam Samarinda ditemukan 15 pasien (9,93\%) yang tidak diberikan antibiotik profilaksis. RS ini type $\mathrm{C}$ dengan status akreditasi lulus 5 jenis pelayanan, namun tidak diketahui statusnya madya atau paripurna Berdasarkan hasil penelitian, juga pada penelitian sebelumnya bahwa pasien yang tidak mendapatkan antibiotik profilaksis merupakan pasien dengan prosedur bedah casarean section. Padahal secara teori, casarean section merupakan prosedur bedah yang termasuk clean-contamined, dan terbukti efektif bahwa pemberian antibiotik profilaksis terhadap prosedur bedah clean-contamined menurunkan angka kejadian infeksi luka operasi (SIGN, 2008). Hal ini juga didukung oleh penelitian yang dilakukan Karminingtyas et al (2018) di Rumah Sakit Islam Sultan Agung Semarang tahun 2016 bahwa keefektifan penggunaan antibiotik profilaksis diukur dengan melihat parameter nilai leukosit dan suhu pasien, dikatakan efektif jika tidak terdapat tanda adanya infeksi yaitu tidak adanya peningkatan suhu yaitu suhu berada $<37,5^{\circ} \mathrm{C}$ dan tidak terjadi peningkatan leukosit atau leukosit berada pada nilai $<11.000 / \mu \mathrm{L}$, sehingga berdasarkan kedua parameter tersebut didapatkan hasil bahwa pasien bedah sesar yang mendapatkan antibiotik profilaksis dikatakan $100 \%$ efektif (Karminingtyas et al., 2018, p.22). RS Islam Sultan Agung dapat melaksanakan prosedur dengan baik dan terbukti efektif, sebab sejak tahun 2014 pun, RS ini sudah mendapat nilai akreditasi yang paripurna. Sulit mencari pembanding RS yang setara akreditasinya dengan RS tempat penelitian ini dilakukan, namun terlihat jelas bahwa penilaian akreditasi yang menghasilkan nilai paripurna akan tergambar salah satunya melalui kepatuhan menjalankan pedoman. 


\section{Jenis Antibiotik}

Dari 76 rekam medik yang memenuhi kriteria inklusi terdapat 119 penggunaan antibiotik profilaksis yang digunakan dalam analisis data, hasil analisis disajikan dalam tabel berikut :

Tabel.2 Data Hasil Evaluasi Penggunaan Antibiotik Profilaksis Berdasarkan Jenis Antibiotik di Rumah Sakit "X" Kota Prabumulih Periode Januari-Desember 2019

\begin{tabular}{|c|c|c|c|c|c|c|}
\hline \multirow[b]{2}{*}{ Golongan } & \multirow{2}{*}{$\begin{array}{c}\text { Jenis } \\
\text { Antibiotik }\end{array}$} & \multicolumn{3}{|c|}{ Kesesuaian Berdasarkan Pedoman } & \multirow[b]{2}{*}{ SP } & \multirow[b]{2}{*}{ TSP } \\
\hline & & (Kemenkes) & (ASHP) & $\begin{array}{c}\text { (NHS } \\
\text { Grampian) }\end{array}$ & & \\
\hline Nitroimidazole & Metronidazole & $\checkmark$ & $\checkmark$ & $\checkmark$ & $\begin{array}{c}34 \\
(28,57 \%) \\
\end{array}$ & - \\
\hline Sefalosporin Generasi ke- II & Cefuroxime & $\checkmark$ & $\checkmark$ & $\checkmark$ & $\begin{array}{c}6 \\
(5,04 \%) \\
\end{array}$ & - \\
\hline \multirow{3}{*}{ Sefalosporin Generasi ke- III } & Cefoperazone & $x$ & $x$ & $x$ & - & $\begin{array}{c}8 \\
(6,72 \%) \\
\end{array}$ \\
\hline & Cefotaxime & $x$ & $\checkmark$ & $x$ & $\begin{array}{c}58 \\
(48,74 \%) \\
\end{array}$ & - \\
\hline & Ceftriaxone & $x$ & $\checkmark$ & $x$ & $\begin{array}{c}10 \\
(8,40 \%) \\
\end{array}$ & - \\
\hline Sefalosporin Generasi ke- IV & Cefpirome & $x$ & $x$ & $x$ & - & $\begin{array}{c}1 \\
(0,84 \%) \\
\end{array}$ \\
\hline $\begin{array}{l}\text { Penisilin } \\
\text { (aminopenisilin) }\end{array}$ & Ampicillin & $\checkmark$ & $\checkmark$ & $x$ & $\begin{array}{c}2 \\
(1,68 \%) \\
\end{array}$ & - \\
\hline \multicolumn{5}{|c|}{ Total } & 110 & 9 \\
\hline \multicolumn{5}{|c|}{ \% Kesesuaian Jenis Antibiotik } & $92,44 \%$ & $7,56 \%$ \\
\hline
\end{tabular}

Keterangan.

Jumlah Antibiotik (n) : 119

ASHP : $\quad$ American Society of Health-

$\begin{array}{lll}\text { NHS } & : & \text { National Health Service } \\ \text { SP } & : & \text { Sesuai Pedoman } \\ \text { TSP } & : & \text { Tidak Sesuai Pedoman }\end{array}$

Jenis antibiotik yang paling banyak digunakan adalah sefalosporin generasi ketiga yaitu cefotaxime sebanyak 58 penggunaan $(48,74 \%)$. Pada beberapa penelitian terkait juga dijumpai bahwa golongan sefalosporin generasi ketiga merupakan antibiotik profilaksis yang paling banyak digunakan (Sumanti et al.,2016, p.22; Karmingtyas et al.,2018; Amelia et al.,2019, p.105; Lisni et al., 2014, p.48). Hasil penelitian yang dilakukan Sumanti et al (2016), p.22 di Rumah Sakit Islam Samarinda menunjukkan bahwa penggunaan antibiotik profilaksis tertinggi yaitu cefotaxime sebesar 73,50\%, dan pada penelitian Karminingtyas et al (2018) di Rumah Sakit Islam Sultan Agung Semarang menunjukkan bahwa penggunaan cefotaxime sebagai antibiotik profilaksis adalah yang paling banyak digunakan yaitu sebesar 66,67\% (Karminingtyas et al., 2018, p.22). Selain itu pada penelitian Amelia et al (2019) penggunaan antibiotik profilaksis pada pasien bedah digesif dan jenis antibiotik yang paling banyak digunakan adalah ceftriaxone sebesar 96,5\%, (Amelia et al.,2019, p.107) dan juga didukung pada penelitian yang dilakukan Lisni et al (2014) di salah satu Rumah Sakit Kota Bandung ditemukan bahwa golongan sefalosporin generasi ketiga merupakan golongan paling banyak digunakan yaitu sebesar 90,84\% (Lisni et al., 2014, p.48).

Berdasarkan Permenkes RI No.2406/Menkes/per/XII/2011 tentang Pedoman Umum Penggunaan Antibiotik bahwa penggunaan antibiotik profilaksis golongan sefalosporin generasi ketiga dan sefalosporin generasi keempat, golongan karbapenem dan golongan kuinolon tidak dianjurkan (Kemenkes RI, 2011). Hal ini dikarenakan golongan tersebut termasuk antibiotik dengan 
spektrum luas (broad spectrum), yang aktif terhadap beberapa jenis kuman, baik kuman gram positif maupun gram negatif dengan aktivitas yang luas sehingga tidak bersifat selektif sedangkan antibiotik spektrum sempit (narrow spectrum) efektif dalam melawan jenis kuman tertentu dan bersifat selektif maka dari itu antibiotik spektrum sempit lebih aktif melawan organisme tunggal dibanding antibiotik spektrum luas (Hakam, 2016, p.115). Penggunaan antibiotik spektrum luas bertolak belakang dengan dasar pemilihan antibiotik profilaksis yaitu dianjurkan menggunakan spektrum sempit. Namun, berdasarkan pedoman dari American Society of Health-System Pharmacists penggunaan cefotaxime dan ceftriaxone merupakan sefalosporin generasi ketiga yang termasuk jenis antibiotik yang direkomendasikan (ASHP, 2013). Maka dari itu penggunaan cefotaxime dan ceftriaxone yang termasuk golongan sefalosporin generasi ketiga, pada penelitian ini dikatakan sesuai karena sesuai dengan salah satu pedoman yang berlaku sedangkan penggunaan cefoperazone dan sefalosporin generasi keempat yaitu cefpirome dikatakan tidak sesuai karena tidak termasuk jenis antibiotik yang direkomendasikan pada ketiga pedoman yang berlaku. (Kemenkes, 2011; ASHP, 2013; NHS Grampian, 2014).

\section{Dosis Antibiotik}

Pemberian Antibiotik profilaksis pada dasarnya diberikan dalam dosis tunggal, namun juga dapat diberikan dosis ulang jika terdapat indikasi pendarahan lebih dari $1500 \mathrm{ml}$ dan apabila operasi berlangsung lebih dari 8 jam, dengan ketentuan bahwa dosis ulang dapat diberikan pada operasi yang berlangsung lebih dari 3 jam dan terdapat indikasi pendarahan lebih dari $1500 \mathrm{ml}$ (NHS Grampian, 2014; Kemenkes, 2011)

Tabel. 3 Data Hasil Evaluasi Penggunaan Antibiotik Profilaksis Berdasarkan Dosis Antibiotik di Rumah Sakit "X” Kota Prabumulih Periode Januari-Desember 2019

\begin{tabular}{|c|c|c|c|c|c|c|c|}
\hline \multirow{2}{*}{ Antibiotik } & \multirow{2}{*}{$\mathbf{N}$} & \multicolumn{2}{|c|}{$\begin{array}{c}\text { Kesesuaian Berdasarkan } \\
\text { Pedoman } \\
\end{array}$} & \multirow{2}{*}{ SP } & \multirow{2}{*}{$\begin{array}{l}\text { TS } \\
\mathbf{P}\end{array}$} & \multicolumn{2}{|c|}{$\%$} \\
\hline & & (ASHP) & (NHS Grampian) & & & SP & TSP \\
\hline \multirow[t]{2}{*}{ Cefotaxime } & \multirow[t]{2}{*}{58} & $1 \mathrm{~g}$ & \multirow{2}{*}{ N/A } & 41 & 0 & $100 \%$ & $0 \%$ \\
\hline & & $2 \mathrm{~g}$ & & 17 & & & \\
\hline Metronidazole & 34 & $500 \mathrm{mg}$ & $500 \mathrm{mg}$ & 34 & - & $100 \%$ & $0 \%$ \\
\hline Ampicillin & 2 & $2 \mathrm{~g}$ & N/A & 2 & 0 & $100 \%$ & $0 \%$ \\
\hline Ceftriaxone & 10 & $2 \mathrm{~g}$ & N/A & 1 & 9 & $10 \%$ & $90 \%$ \\
\hline Cefuroxime & 6 & $1,5 \mathrm{~g}$ & $1,5 \mathrm{~g}$ & - & 6 & $0 \%$ & $100 \%$ \\
\hline \multirow[t]{2}{*}{ Total } & 110 & & & 95 & 15 & & \\
\hline & \multicolumn{3}{|c|}{ \% Kesesuaian Dosis } & & & $86,36 \%$ & $13,63 \%$ \\
\hline
\end{tabular}

\section{Keterangan}

ASHP : American Society of Health-System Pharmacists

$\mathrm{N} \quad$ : Jumlah penggunaan antibiotik

NHS : $\quad$ National Health Service

N/A : Not Applicable / tidak berlaku

SP : $\quad$ Sesuai Pedoman

TSP : $\quad$ Tidak Sesuai Pedoman

Namun, dari data yang terkumpul tidak terdapat keterangan yang menunjukkan adanya indikasi pendarahan $>1500 \mathrm{ml}$. Berdasarkan keterangan yang diberikan perawat OK (kamar operasi) bahwa rata-rata lama operasi berlangsung yaitu Appendectomy sekitar 1 jam, Casarean section sekitar 1.5 jam, dan Transurethal resection of the prostate sekitar $1.5 \mathrm{jam}$. Maka, dapat diketahui bahwa lama operasi yang berlangsung tidak lebih dari 3 jam sehingga dosis ulang seharusnya 
tidak diberikan. Namun, berdasarkan pedoman American Society of Health-System Pharmacists, dosis ulang dapat diberikan sesuai dengan dosis yang tertera pada pedoman (ASHP, 2013).

Terdapat ketidaksesuaian dosis antibiotik yang diberikan dengan pedoman yang berlaku. Dosis penggunaan ceftriaxone yang direkomendasikan pedoman American Society of Health-System Pharmacists (2013) yaitu sebesar 2 gram (ASHP,2013, p.736), namun hasil yang didapatkan bahwa hanya ada 1 penggunaan ceftriaxone yang diberikan dosis 2 gram sedangkan 9 penggunaan lainnya diberikan sebesar 1 gram. Untuk penggunaan cefuroxime dinyatakan sesuai jika dosis yang digunakan sebesar 1,5 gram sedangkan hasil penelitian yang didapat keseluruhan penggunaan cefuroxime diberikan dosis sebesar 1 gram.

\section{Rute Pemberian}

Tabel.4 Data Hasil Evaluasi Penggunaan Antibiotik Profilaksis Berdasarkan Rute Pemberian di Rumah Sakit "X” Prabumulih Periode Januari-Desember 2019

\begin{tabular}{cccccc}
\hline \multirow{2}{*}{ Antibiotik } & \multirow{2}{*}{$\mathbf{N}$} & \multicolumn{2}{c}{ Kesesuaian Rute Pemberian } & \% \\
\cline { 3 - 6 } & & Sesuai & Tidak Sesuai & S & TS \\
\hline Cefotaxime & 58 & 58 & 0 & $100 \%$ & $0 \%$ \\
Metronidazole & 34 & 34 & 0 & $100 \%$ & $0 \%$ \\
Ceftriaxone & 10 & 10 & 0 & $100 \%$ & $0 \%$ \\
Cefuroxime & 6 & 6 & 0 & $100 \%$ & $0 \%$ \\
Ampicillin & 2 & 2 & 0 & $100 \%$ & $0 \%$ \\
\hline Total & $\mathbf{1 1 0}$ & $\mathbf{1 1 0}$ & $\mathbf{0}$ & $100 \%$ & $0 \%$ \\
\hline
\end{tabular}

\section{Keterangan}

$\mathrm{S} \quad$ : Sesuai

TS : Tidak Sesuai

*Sesuai jika rute pemberian melalui Iv ( Intravena)

Secara keseluruhan, rute pemberian pada penelitian ini sesuai dengan pedoman yaitu diberikan secara intravena. Kesesuaian rute pemberian juga ditunjukkan pada penelitian yang dilakukan Oktavaiani et al (2015) yang menunjukkan bahwa kesesuaian rute pemberian sebesar 100\% (Oktaviani et al.,2015, p.255) dan juga penelitian yang dilakukan Rusdiana et al (2016) bahwa persentase rute pemberian antibiotik profilaksis sebesar 100\% (Rusdiana et al.,2016, p.74). Hal ini menunjukkan bahwa rute pemberian antibiotik profilaksis pada beberapa penelitian dari tahun ke tahun sudah sesuai. Pada berbagai penggunaan jenis antibiotik membutuhkan waktu yang berbeda dalam mencapai kadar yang dibutuhkan untuk dapat menghambat pertumbuhan kuman. Umumnya, kadar yang dibutuhkan 3-4 kali kadar hambat minimum, oleh karena itu antibiotik profilaksis biasanya diberikan secara parenteral yaitu agar antibiotik cepat didistribusikan (Sjamsuhidajat \& de jong, 2017) dan menurut Ganiswara (2017), pemberian antibiotik secara intravena cepat didistribusikan sehingga antibiotik yang diberikan segera mencapai jaringan dan memberikan efek terapi. 


\section{Waktu Pemberian}

Tabel.5 Data Hasil Evaluasi Penggunaan Antibiotik Profilaksis Berdasarkan Waktu Pemberian di Rumah Sakit "X” Prabumulih Periode Januari-Desember 2019

\begin{tabular}{|c|c|c|c|c|c|c|c|}
\hline \multirow[b]{2}{*}{ Antibiotik } & \multirow[b]{2}{*}{$\mathbf{N}$} & \multicolumn{3}{|c|}{ Kesesuaian Berdasarkan Pedoman (SP) } & \multirow[b]{2}{*}{ TSP } & \multicolumn{2}{|c|}{$\%$} \\
\hline & & $\begin{array}{l}\text { Kemenkes } \\
\text { ( } \leq 30 \text { menit) }\end{array}$ & $\begin{array}{c}\text { NHS Tayside } \\
\text { ( } \leq 60 \text { menit) }\end{array}$ & $\begin{array}{l}\text { WHO } \\
\text { ( } \leq 120 \\
\text { menit }) \\
\end{array}$ & & SP & TSP \\
\hline Metronidazole & 34 & - & 34 & - & 0 & $100 \%$ & $0 \%$ \\
\hline Ceftriaxone & 10 & - & 10 & - & 0 & $100 \%$ & $0 \%$ \\
\hline Ampicillin & 2 & - & 2 & - & 0 & $100 \%$ & $0 \%$ \\
\hline Cefotaxime & 58 & - & 52 & - & 6 & $89,66 \%$ & $10,34 \%$ \\
\hline Cefuroxime & 6 & - & 5 & - & 1 & $83,33 \%$ & $16,67 \%$ \\
\hline Total & 110 & - & 103 & - & 7 & $93,64 \%$ & $6,36 \%$ \\
\hline
\end{tabular}

\section{Keterangan}

*waktu pemberian : waktu diberikan antibiotik profilaksis sebelum dilakukannya insisi kulit

\begin{tabular}{|c|c|c|c|}
\hline $\mathrm{N}$ & Jumlah penggunaan antibiotik & TSP & Tidak Sesuai Pedoman \\
\hline NHS & National Health Service & WHO & World Health Organization \\
\hline
\end{tabular}

SP : Sesuai Pedoman

Berdasarkan Permenkes RI No.2406/Menkes/per/XII/2011 tentang Pedoman Umum Penggunaan Antibiotik dan SIGN 104 Antibiotic prophylaxis in surgery : A national clinical guideline bahwa antibiotik profilaksis diberikan $\leq 30$ menit sebelum dilakukan insisi kulit pada pasien, dan idealnya diberikan pada saat induksi anastesi saat akan dilakukan pembedahan (Kemenkes, 2011; SIGN, 2008) serta waktu optimal pemberian antibiotik profilaksis yaitu 60 menit sebelum insisi kulit (SAPG, 2018). Namun menurut World Health Organization, tidak ada perbedaan signifikan terhadap waktu pemberian antara 120-60 menit vs 60-0 menit, 60-30 menit vs 30-0 menit, antibiotik profilaksis dapat diberikan sampai 120 menit sebelum insisi kulit, dan tidak lebih dari 120 menit (WHO, 2016, p.71), sehingga ketidaksesuaian waktu pemberian ini merupakan antibiotik profilaksis yang diberikan $>120$ menit setelah inisisi kulit pada tindakan pembedahan. Kesesuaian waktu pemberian pada penelitian ini lebih tinggi jika dibandingkan dengan penelitian sebelumnya, yaitu sebesar 93,64\% sedangkan kesesuaian waktu pemberian pada penelitian tahun 2015 sebesar 72,9\% (Oktaviani et al., 2015, p.255).

\section{Interval Pemberian}

Tabel.6 Data Hasil Evaluasi Penggunaan Antibiotik Profilaksis Berdasarkan Interval Pemberian Pemberian di Rumah Sakit "X” Prabumulih Periode Januari-Desember 2019

\begin{tabular}{|c|c|c|c|c|c|c|c|}
\hline \multirow{2}{*}{ Antibiotik } & \multirow{2}{*}{$\mathbf{N}$} & \multicolumn{2}{|c|}{ Kesesuaian Berdasarkan Pedoman } & \multirow{2}{*}{ SP } & \multirow{2}{*}{ TSP } & \multicolumn{2}{|c|}{$\%$} \\
\hline & & (ASHP) & (NHS Grampian) & & & SP & TSP \\
\hline Cefuroxime & 6 & $4 \mathrm{jam}$ & $4 \mathrm{jam}$ & 1 & 5 & $16,67 \%$ & $83,33 \%$ \\
\hline Cefotaxime & 58 & $3 \mathrm{jam}$ & N/A & 6 & 52 & $10,34 \%$ & $89,66 \%$ \\
\hline Ceftriaxone & 10 & N/A & N/A & 1 & 9 & $10 \%$ & $90 \%$ \\
\hline Metronidazole & 34 & N/A & 8 jam & 0 & 34 & $0 \%$ & $100 \%$ \\
\hline Ampicillin & 2 & 2 jam & N/A & 0 & 2 & $0 \%$ & $100 \%$ \\
\hline Total & 110 & & & 8 & 102 & & \\
\hline \multicolumn{4}{|c|}{ \% Kesesuaian Interval Pemberian } & & & $7,27 \%$ & $92,73 \%$ \\
\hline
\end{tabular}




\section{Keterangan}

ASHP : American Society of HealthSystem Pharmacists

$\mathrm{N} \quad$ : Jumlah penggunaan antibiotik

N/A : Not Applicable / tidak berlaku

$\begin{array}{lll}\text { NHS } & : & \text { National Health Service } \\ \text { SP } & : & \text { Sesuai Pedoman } \\ \text { TSP } & : & \text { Tidak Sesuai Pedoman }\end{array}$

Kesesuaian interval pemberian pada penelitian ini pemberian masih relatif rendah dibandingkan dengan penelitan sebelumnya. Pada penelitian sebelumnya mengenai evaluasi penggunaan antibiotik profilaksis terhadap pasien bedah sesar bahwa kesesuaian interval pemberian sebesar 100\% (Oktaviani et al.,2015, p.255). Jika dosis antibiotik diberikan diberikan dalam dosis tunggal maka interval pemberian tidak berlaku karena tidak adanya pemberian dosis ulang dan dilihat dari hasil penelitian bahwa interval pemberian berpengaruh terhadap lama pemberian, jika antibiotik profilaksis diberikan dalam dosis tunggal maka lama pemberian tidak $>24$ jam, namun pada penelitian ini kesesuaian interval pemberian masih relatif rendah, sehingga pada lama pemberian masih banyak antibiotik profilaksis yang diberikan $>24$ jam.

\section{Lama Pemberian}

Berdasarkan Permenkes RI No.2406/Menkes/per/XII/2011 tentang Pedoman Umum Penggunaan Antibiotik dan Global Guidelines for the Prevention of Surgical Site Infection bahwa pemberian antibiotik profilaksis diberikan sebelum, saat, hingga 24 jam setelah tindakan pembedahan dilakukan (Kemenkes, 2011; WHO, 2016). Pada penelitian yang dilakukan oleh Amelia et al (2019) bahwa 71\% lama pemberian yang diberikan > 48 jam (Amelia et al 2019, p.105) dan berdasarkan hasil penelitian Megawati et al (2015) menunjukkan bahwa sebanyak $169(99,4 \%)$ penggunaan diberikan lebih dari 24 jam (Megawati et al., 2015, p.131).

Tabel.7 Data Hasil Evaluasi Penggunaan Antibiotik Profilaksis Berdasarkan Lama Pemberian di Rumah Sakit "X” Prabumulih Periode Januari-Desember 2019

\begin{tabular}{lccccc}
\hline \multirow{2}{*}{ Antibiotik } & \multirow{N}{*}{$\mathbf{N}$} & \multicolumn{2}{c}{ Kesesuaian Lama Pemberian } & \multicolumn{2}{c}{$\%$} \\
\cline { 2 - 6 } & & Sesuai & Tidak Sesuai & S & TS \\
\hline Cefuroxime & 6 & 3 & 3 & $50 \%$ & $50 \%$ \\
Cefotaxime & 58 & 26 & 32 & $44,83 \%$ & $55,17 \%$ \\
Metronidazole & 34 & 13 & 21 & $38,24 \%$ & $61,76 \%$ \\
Ceftriaxone & 10 & 2 & 8 & $20 \%$ & $80 \%$ \\
Ampicillin & 2 & 0 & 2 & $0 \%$ & $100 \%$ \\
\hline \multicolumn{7}{c}{ Total } & $\mathbf{1 1 0}$ & $\mathbf{4 4}$ & $\mathbf{6 6}$ & & \\
\hline \multicolumn{7}{c}{ \% Kesesuaian Lama Pemberian } & $\mathbf{4 0 \%}$ & $\mathbf{6 0 \%}$ \\
\hline
\end{tabular}

\section{Keterangan}

*Sesuai jika lama pemberian $\leq 24$ jam

$S$ : Sesuai

*Tidak sesuai jika lama pemberian > 24 jam

TS : Tidak Sesuai

Hasil penelitian menunjukan bahwa ketidaksesuaian lama pemberian masih relatif lebih rendah dibanding penelitian sebelumnya. Kemungkinan diberikannya antibiotik dalam waktu yang panjang dikarenakan adanya kekhawatiran terhadap infeksi yang mungkin terjadi, dan juga berdasarkan faktor-faktor yang muncul pada pasien, sehingga diberikan antibiotik dalam waktu yang lebih lama sebagai bentuk pemeliharaan. Namun, hal ini tidak mengacu pada tujuan pemberian antibiotik profilaksis menurut Kemenkes (2011) bahwa antibiotik profilaksis 
diberikan sebagai upaya pencegahan dalam menurunkan resiko terjadinya infeksi luka operasi atau Surgical Site Infection (SSI) yang diberikan sebelum, saat, maupun 24 jam setelah tindakan pembedahan, menghambat munculnya resistensi, menurunkan morbiditas dan mortalitas pasien, dan meminimalkan biaya pelayanan kesehatan. Dalam hal ini hasil penelitian bertolak belakang dengan tujuan antibiotik profilaksis. Untuk selanjutnya perlu adanya tindak lanjut untuk meneliti pengaruh lama pemberian terhadap kejadian Surgical Site Infection (SSI).

\section{Kesesuaian Penggunaan}

Berdasarkan analisa yang dilakukan terhadap jenis antibiotik, dosis antibiotik, rute pemberian, waktu pemberian, interval pemberian, dan lama pemberian, maka hasil analisa disajikan dalam tabel berikut :

Tabel 8. Evaluasi Penggunaan Antibiotik Profilaksis Berdasarkan Keseluruhan Variabel di Rumah Sakit "X" Kota Prabumulih Periode Januari-Desember 2019

\begin{tabular}{lcc}
\hline \multicolumn{1}{c}{ Penggunaan Antibiotik Profilaksis } & Jumlah & \% \\
\hline Sesuai Jenis Antibiotik & 110 & $92,44 \%$ \\
\hline Sesuai Jenis Antibiotik dan Dosis & 95 & $79,83 \%$ \\
\hline Sesuai Jenis Antibiotik, Dosis, dan Rute Pemberian & 95 & $79,83 \%$ \\
\hline $\begin{array}{l}\text { Sesuai Jenis Antibiotik, Dosis, Rute Pemberian dan Waktu } \\
\text { Pemberian. }\end{array}$ & 89 & $74,79 \%$ \\
\hline $\begin{array}{l}\text { Sesuai Jenis Antibiotik, Dosis, Rute Pemberian Waktu } \\
\text { Pemberian dan Interval Pemberian }\end{array}$ & 8 & $6,72 \%$ \\
\hline $\begin{array}{l}\text { Sesuai Jenis Antibiotik, Dosis, Rute Pemberian Waktu } \\
\text { Pemberian, Interval Pemberian, dan Lama Pemberian }\end{array}$ & 8 & $6,72 \%$ \\
\hline \multicolumn{1}{c}{ Kesesuaian Seluruh Variabel } & $\mathbf{8}$ & $\mathbf{6 , 7 2 \%}$ \\
\hline
\end{tabular}

Pada penelitian ini, penggunaan antibiotik profilaksis belum sepenuhnya sesuai secara keseluruhan yaitu hanya 8 penggunaan $(6,72 \%)$ yang sesuai. Pada penelitian sebelumnya, yaitu menurut hasil penelitian Oktaviani et al (2015),p.255 bahwa kesesuaian penggunaan antibiotik berdasarkan jenis antibiotik sebesar 34,3\%, dosis sebesar $65,7 \%$, rute pemberian sebesar $100 \%$, dan waktu pemberian sebesar $72,9 \%$. Dalam hal ini perlunya optimalisasi penerapan penggunaan antibiotik profilaksis yang sesuai sehingga disarankan bagi rumah sakit untuk membuat pedoman khusus mengenai penggunaan antibiotik profilaksis. Berdasarkan Scottish Intercollegiate Guidelines Network (2008), penggunaan antibiotik profilaksis terhadap prosedur bedah kategori not recommended secara klinis belum terbukti efektif, hanya menurunkan morbiditas dalam jangka pendek, dan kemungkinan kecil dalam mengurangi konsumsi antibiotik pasien secara keseluruhan (SIGN, 2008). Maka, untuk penelitian selanjutnya, diharapkan dapat dilakukan penelitian mengenai identifikasi penggunaan antibiotik profilaksis pada kategori prosedur bedah not recommended.

\section{KESIMPULAN DAN SARAN}

Penggunaan antibiotik profilaksis ditinjau dari jenis antibiotik, dosis dan rute pemberian sudah sesuai pedoman, sedangkan ketidaksesuaian masih ditemukan pada interval waktu serta lamanya pemberian antibiotik.

Selanjutnya diharapkan dapat dilakukan penelitian mengenai Cost Effective Analysis terhadap pemberian antibiotik profilaksis di Rumah Sakit dan penelitian mengenai efektivitas penggunaan antibiotik profilaksis pada prosedur bedah kategori not recommended. 


\section{REFERENSI}

Amelia, K.,Sumarny, R., Hasan, D., \& Komar,H. (2019). Kajian Pola Penggunaan Antibiotik Profilaksis dan Diagnosa Pascaoperasi Hubungannya dengan Angka Kejadian Infeksi Daerah Operasi (IDO) pada Pasien Bedah di Rumah Sakit Swasta. Jurnal Ilmiah Kedokteran, 6 (2), 104-112. Diakses 03 Januari 2020. Available at : http://jurnal.untad.ac.id/jurnal/index.php/MedikaTadulako/article/download/13627/10421

Antoni, P., \& Supadmi, W. (2016). Evaluasi Kerasionalan Penggunaan Antibiotika Profilaksis di Instalasi Bedah RSUD Tugurejo Semarang Periode April 2014. Jurnal Kefarmasian Akfarindo, 1(1), 1-9. Diakses 02 Januari 2020. Available at : http://jofar.afi.ac.id/index.php/jofar/article/view/1/1

ASHP. (2013). Clinical Practice Guidelines for Antimicrobial Prophylaxis in Surgery. American Society of Health System Pharmacists, USA. Diakses 13 Desember 2020. Available at : https://www.ashp.org/-/media/assets/policy-guidelines/docs/therapeuticguidelines/therapeutic-guidelines-antimicrobial-prophylaxis-surgery.ashx

Badan Penelitian dan Pengembangan Kesehatan. (2013). Riset Kesehatan Dasar (Riskesdas) 2013. Jakarta: Kementerian Kesehatan Republik Indonesia. Diakses 17 Maret 2020. https://kemkes.go.id/resources/download/general/Hasil\%20Riskesdas\%202013.pdf

Badan Penelitian dan Pengembangan Kesehatan. (2019). Laporan Nasional Riset Kesehatan Dasar (Riskesdas) 2018. Jakarta: Kementerian Kesehatan Republik Indonesia. Diakses 17 Maret 2020. Available at http://labdata.litbang.kemkes.go.id/images/download/laporan/RKD/2018/Laporan_Nasiona 1_RKD2018_FINAL.pdf

Ganiswara,G. (2017). Farmakologi dan Terapi (edisi 6). Departemen Farmakologi Fakultas Kedokteran Universitas Indonesia, Jakarta.

Goranitis, I., Lissauer, D.M., Coomarasamy,A., Wilson,A., Daniels,J., et al. (2019). Antibiotic Prophylaxis in the Surgical Management of Miscarriage in Low-Income Countries: "A Cost-Effectiveness Analysis Of The Aims Trial". Lancet Global Health, 7(9), 1280-1286. Diakses 03 Januari 2020. Available at : https://doi.org/10.1016/S2214-109x(19)30336-5

Hakam, Mulia. (2016). Hubungan Antibotika Golongan Beta Laktam melalui Infusa dengan Kejadian Plebitis. NurseLine Journal, 1(2), 114-119. Diakses 11 Januari 2020. Available at : https://media.neliti.com/media/publications/197103-ID-correlation-between-the-infusionof-beta.pdf

Hamidy, M. Y., Fauzia, D., Nugraha, D.P., \& Muttaqien, M.I. (2016). Penggunaan Antibiotik Profilaksis Bedah pada Sectio Cesarea di RSUD Arifin Achmad Provinsi Riau. Jurnal Ilmu Kedokteran, 10(1), 33-37. https://doi.org/ 10.26891/jik.v10i1.2016.33-37

Karminingtyas, S. R., Oktianti,D., \& Furdiyanti,N.H. (2018). Keefektifan Penggunaan Antibiotik Profilaksis pada Pasien Bedah Sesar (Sectio Caesarea). Cendekia Journal of Pharmacy. 2(1), 22-31. Diakses 19 Januari 2020. Available at : https://doi.org/ 10.31596/Cjp.V2i1.14

Kemenkes RI. (2011). Pedoman Umum Penggunaan Antibiotik. Kementerian Kesehatan Republik Indonesia, Jakarta. Diakses 17 Maret 2020. Available at : http://farmalkes.kemkes.go.id/unduh/pedoman-umum-penggunaanantibiotik/?ind $=1605252737381 \&$ filename $=$ Pedoman $\% 20$ Umum $\% 20$ Penggunan $\% 20$ Antib iotik.pdf \&wpdmdl=9965\&refresh=605da9601365a1616750944

Kemenkes RI. (2017). Pedoman Pencegahan dan Pengendalian Infeksi di Fasilitas Pelayanan Kesehatan. Kementerian Kesehatan Republik Indonesia, Jakarta. Diakses 17 Maret 2020. Available 
http://hukor.kemkes.go.id/uploads/produk_hukum/PMK_No._27_ttg_Pedoman_Pencegaha n_dan_Pengendalian_Infeksi_di_FASYANKES_pdf

Lisni, I., Permana,T.A., \& Sutrino,E. (2014). Evaluasi Penggunaan Antibiotik Profilaksis pada Pasien Bedah di Salah Satu Rumah Sakit Kota Bandung. Jurnal Farmasi Galenika. 1(2),48-53. Diakses 19 Januari 2020. Available at : https://jfg.stfb.ac.id/index.php/jfg/article/view/19/14

Megawati,S., Rahmawati,F., \& Wahyono,D. (2015). Evaluasi Penggunaan Antibiotik Profilaksis Pada Pasien Bedah. Jurnal Manajemen dan Pelayanan Farmasi. 5(2), 127-134. Diakses 04 Februari 2020. Available at : https://doi.org/10.22146/jmpf.138

Muthoharoh, A., Diana,N., Rahmatullah,St., \& Wirasti,W. (2019). Evaluasi Kualitatif Penggunaan Antibiotika Profilaksis di Instalasi Bedah Sentral Secara Retrospektif'. Proceeding of the Urecol, 490-497. Diakses 19 Januari 2020. Available at : https://repository.urecol.org/index.php/proceeding/article/download/386/376/

NHS Grampian. (2014). Surgical Antibiotic Prophylaxis Guidelines. National Health Service Grampian Antimicrobial Management Team, Aberdeen.

NHS Tayside Antimicrobial Management Group. (2019). Antibiotic Prophylaxis in General Surgery. National Health Service Tayside Antimicrobial Management Group, Dundee. Diakses 27 Desember 2020. Available at : https://www.nhstaysideadtc.scot.nhs.uk/Antibiotic\%20site/pdf\%20docs/Antibiotic\%20pro phylaxis\%20in\%20gen\%20surgery.pdf

Oktaviani,F., Wahyono,D., \& Yuniarti,E. (2015). Evaluasi Penggunaan Antibiotik Profilaksis Terhadap Kejadian Luka Operasi Sectio Caesarea. Jurnal Manajemen dan Pelayanan Farmasi,5(4), 255-258. Diakses 02 Februari 2020. Available at : https://journal.ugm.ac.id/jmpf/article/view/29449/17593

Rusdiana,N.,Safitri,M. \& Resti,A. (2016). Evaluasi Penggunaan Antibiotik Profilaksis Pada Pasien Bedah Terencana di Rumah Sakit Ibu dan Anak "X" di Tangerang. Social Clinical Pharmacy Indonesia Journal, 1(1), 67-75. Diakses 12 Januari 2020. Available at : https://123dok.com/document/download/z31orm8y

SAPG. (2018). Recommendations for Re-dosing Antibiotics for Surgical Prophylaxis. Healthcare Improvement Scotland. Diakses 14 Desember 2019. Available at : https://www.sapg.scot/media/4105/good-practice-recommendations-for-re-dosingantibiotics-for-surgical-prophylaxis.pdf

SIGN. (2008). SIGN 104 Antibiotic prophylaxis in surgery : "A national clinical guideline". Scottish Intercollegiate Guidelines Network, Edinburgh. Diakses pada 29 Desember 2019. Available at http://www.just.edu.jo/ar/DIC/ClinicGuidlines/Antibiotic\%20prophylaxis\%20in\%20surg ery.pdf

Sjamsuhidajat,R., \& de jong. (2017). Buku Ajar Ilmu Bedah ed.4 (1). Penerbit Buku kedokteran EGC, Jakarta, Indonesia. 
Sumanti, E.W., Ayu, W.D., \& Rusli,R. (2016). "Pola Penggunaan Antibiotik Profilaksis pada Pasien Bedah Sesar (Sectio Caesarean) di Rumah Sakit Islam Samarinda". Prosiding Seminar Nasional Kefarmasian Ke-3. Fakultas Farmasi Universitas Mulawarman, Samarinda, 20-21 April 2016. Diakses 02 Januari 2020. Available at : https://doi.org/10.25026/mpc.v3i1.63

WHO. (2015). WHO Recommendation on Antibiotic Prophylaxis for Casarean Section Using a Single Dose of First Generation Cephalosporin or Penisilin in Preference to Other Classes of Antibiotics. Diakses 12 Januari 2020. Available at : https://extranet.who.int/rhl/topics/preconception-pregnancy-childbirth-and-postpartumcare/who-recommendation-antibiotic-prophylaxis-casarean-section-using-single-dosefirst-generation

WHO. (2016). Global Guidelines for the Prevention of Surgical Site Infection. World Health Organization, Switzerland. Diakses 10 Januari 2020. Available at : https://apps.who.int/iris/bitstream/handle/10665/250680/9789241549882eng.pdf? sequence $=8$

Yuwono. (2013). Pengaruh Beberapa Faktor Risiko Terhadap Kejadian Surgical Site Infection ( SSI ) Pada Pasien Laparotomi Emergensi. Jmj. 1(1), 16-26. Diakses 10 Januari 2020. Available at : https://eprints.unsri.ac.id/3161/1/JMI_SSI.pdf 
EVALUASI PENGGUNAAN ANTIBIOTIK PROFILAKSIS PADA PASIEN BEDAH KATEGORI HIGHLY RECOMMENDED DI RUMAH SAKIT “X” KOTA PRABUMULIH
Rangti Annisa Harartasyahrani, et.al. 